(C) 2014

Стельмах О. М., старший науковий співробітник, Григорів Я. Я., молодший науковий співробітник, аспірант (науковий керівник - доктор сільськогосподарських наук В. Ф. Камінський)

Максимів Т. О., молодший науковий співробітник

Прикарпатська державна сільськогосподарська дослідна НААН України

\title{
ФОТОСИНТЕТИЧНА ДІЯЛЬНІСТЬ РОСЛИН РИЖІЮ ЯРОГО ЗАЛЕЖНО ВІД ТЕХНОЛОГІЧНИХ ПРИЙОМІВ ВИРОЩУВАННЯ
}

\author{
Рецензент - кандидат сільськогосподарських наук Н. М. Лис
}

\begin{abstract}
Наведено результати досліджень із вивчення впливу технологічних прийомів вирощування на динаміку наростання площзі листків та формування фотосинтетичного потенціалу посівів. За результатами досліджень встановлено, щзо найвищуі показники площі листкової поверхні отримані за першого строку сівби у фазу иввітіння рижію ярого. Встановлено, щзо внесення мінеральних добрив мало суттєвий вплив на площу листкової поверхні рижію ярого й, відповідно, на показник фотосинтетичного потенціалу.
\end{abstract}

Ключові слова: рижій ярий, площуа листків, фотосинтетичний потенціал, технологї.

Постановка проблеми. Продукційний процес рослин складається 3 фотосинтезу та процесів перетворення й використання продуктів та енерriï фотосинтетичного походження на дихання, біосинтез, ріст і розвиток рослинного організму. Завдання отримати найбільшу кількість органічної речовини полягає в тому, щоб створити фотосинтезуючі системи, які б забезпечили найбільш ефективне використання енергії фотосинтетично активної радіації (ФАР) на утворення продуктів фотосинтезу та раціонального використання їх у процесах росту, розвитку й формування продуктивності сільськогосподарських культур [3].

Тому програмою наших досліджень із метою виявлення залежностей формування фотосинтетичного апарату рижію ярого впродовж вегетаційного періоду було передбачено визначення таких показників фотосинтетичної діяльності рослин як площа листкової поверхні та фотосинтетичний потенціал.

Аналіз останніх досліджень і публікацій, у яких започатковано розв'язання проблеми. Уже відомо, що 90-95 \% сухої речовини врожаю культурних рослин створюється за рахунок фотосинтезу, який проходить у листках, де під впливом засвоюваної сонячної енергії з вуглекислого газу та води створюються речовини, що становлять основну i найбільш цінну частину врожаю. У зв'язку 3 цим урожайність сільськогосподарських культур у значній мірі залежить від динаміки наростання площі листків рослин та інтенсивності ї роботи впродовж вегетаційного періоду. Площа листкової поверхні є досить змінною величиною, на формування якої істотно впливають умови вологозабезпечення, мінерального живлення та інші технологічні прийоми вирощування [4].

Хід процесу формування площі листків і iï розміри, насамперед, можуть визначатися густотою посівів рослин.

Посіви зі значною густотою рослин швидше формують велику площу листків, однак це негативно позначається на закладанні, формуванні й розвитку репродуктивних органів. Із цієї точки зору окремі рослини в розріджених посівах знаходяться в значно кращих умовах.

Аби такий розріджений посів зімкнувся й на кожному гектарі утворилась достатньо велика площа листків (40-45 тис. м $^{2}$ ), кожна окрема рослина повинна досягати великих розмірів і утворювати велику площу листків $[4,5]$.

Отже, процес формування листкової поверхні може бути як показником ступеня забезпечення посівів елементами мінерального живлення, так i показником ступеня відповідності густоти посівів, фенологічних процесів, тривалості основних фаз росту й розвитку [5].

Мета дослідження - вивчення впливу технологічних прийомів вирощування рижію ярого на фотосинтетичну діяльність рослин в умовах Прикарпаття України.

Завдання: вдосконалити технологію вирощування рижію ярого в умовах Прикарпаття України для формування кращих показників листкової поверхні та фотосинтетичного потенціалу рослин.

Матеріал і методика досліджень. Дослідження проводили протягом 2011-2013 рр. на дослідному полі технологічної сівозміни Прикарпатської державної дослідної станції НААН України. 


\section{СІЛЬСЬКЕ ГОСПОДАРСТВО. РОСЛИННИЦТВО}

Грунти дослідної ділянки - дернові глибоко опідзолено глеюваті 3 наступною агрохімічною характеристикою орного шару $(0-25 \mathrm{~cm}): \mathrm{pH}$ (сольове) $-5,1$; вміст гумусу $-2,76 \%$; азоту $-67,0$; фосфору - 78,0; калію - 114,0 мг на 1 кг грунту. Дослід закладений у 3 -кратній повторності.

Загальна кількість ділянок - 24, посівна площа однієї ділянки $-75 \mathrm{~m}^{2}$, облікової - $45 \mathrm{~m}^{2}$. Розміщення ділянок - систематичне.

Попередник - пшениця озима. Посів проводили згідно зі схемою досліду. Для посіву використовували сорт Гірський селекції інституту АПВ.

Зважаючи на нечутливість рижію до внесення калійних добрив, вивчали вплив лише азотних i фосфорних добрив.

У досліді мінеральні добрива у вигляді аміачної селітри й гранульованого суперфосфату вносили під основний обробіток грунту за схемою:

1. Контроль - без добрив.

2. ФоH $-\left(\mathrm{N}_{0} \mathrm{P}_{45} \mathrm{~K}_{45}\right)$.

3. Фон $-\left(\mathrm{N}_{30} \mathrm{P}_{45} \mathrm{~K}_{45}\right)$.

4. $\Phi$ OH $-\left(\mathrm{N}_{30} \mathrm{P}_{45} \mathrm{~K}_{45}\right)+\mathrm{N}_{60}$.

5. Фон - $\left(\mathrm{N}_{30} \mathrm{P}_{45} \mathrm{~K}_{45}\right)+\mathrm{N}_{30}$.

Закладання дослідів і проведення досліджень виконували у відповідності з загальноприйнятими методиками польових дослідів у землеробстві та рослинництві.

На всіх варіантах дослідів проводилися фенологічні спостереження; біометричні й фізіолого-біохі- мічні дослідження проводили за методиками Г. Л. Бондаренка, К. І. Яковенка, В. Ф. Мойсейченка $[1,2]$.

Результати досліджень. У дослідженнях вивчали вплив технології вирощування на площу листкової поверхні фотосинтетичного потенціалу посівів рижію ярого.

Встановлено криволінійний характер формування показників площі листкової поверхні в онтогенезі рижію ярого залежно від впливу досліджуваних чинників (табл. 1).

У результаті проведених досліджень встановлено, що найбільша площа листкової поверхні спостерігалася за першого строку сівби на всіх стадіях розвитку рослин.

Застосування мінеральних добрив сприяє більш інтенсивному розвиткові листкової поверхнi.

В ході досліджень нами було встановлено динаміку формування площі листкової поверхні в основні періоди росту рижію ярого.

У період формування двох справжніх листків залежності між площею листкової поверхні й дозами удобрення не було встановлено.

Водночас різницю між строками сівби було відмічено: посіви за першого строку сівби мали дещо вищу площу листкової поверхні порівняно 3 другим і третім.

1. Формування листкової поверхні рижію ярого за фазами розвитку залежно від різних технологічних приймів вирощування, середнє за 2011-2013 рp., тис. м $^{2} / 2 a$

\begin{tabular}{|c|c|c|c|c|c|}
\hline \multirow{2}{*}{ Строк сівби } & \multirow{2}{*}{ Варіант удобрення } & \multicolumn{4}{|c|}{ Фази росту і розвитку } \\
\hline & & стеблування & бутонізація & цвітіння & дозрівання \\
\hline \multirow{5}{*}{$\begin{array}{c}\text { 1-й строк сівби - } \\
\text { температура } \\
\text { грунту } 1-2{ }^{0} \mathrm{C}\end{array}$} & без добрив (контроль) & 0,75 & 4,62 & 8,80 & 4,39 \\
\hline & $\mathrm{P}_{45} \mathrm{~K}_{45}$ & 0,82 & 4,87 & 8,86 & 4,61 \\
\hline & $\mathrm{N}_{30} \mathrm{P}_{45} \mathrm{~K}_{45}$ & 1,15 & 5,31 & 9,22 & 5,15 \\
\hline & $\mathrm{N}_{30} \mathrm{P}_{45} \mathrm{~K}_{45}+\mathrm{N}_{60}$ & 0,95 & 5,09 & 9,09 & 4,88 \\
\hline & $\mathrm{N}_{30} \mathrm{P}_{45} \mathrm{~K}_{45}+\mathrm{N}_{30}$ & 1,08 & 5,08 & 9,07 & 4,79 \\
\hline \multirow{5}{*}{$\begin{array}{c}\text { 2-й строк сівби - } \\
\text { через } 5 \text { днів }\end{array}$} & без добрив (контроль) & 0,56 & 3,88 & 6,88 & 3,67 \\
\hline & $\mathrm{P}_{45} \mathrm{~K}_{45}$ & 0,60 & 4,21 & 7,14 & 3,89 \\
\hline & $\mathrm{N}_{30} \mathrm{P}_{45} \mathrm{~K}_{45}$ & 0,80 & 4,79 & 7,30 & 4,18 \\
\hline & $\mathrm{N}_{30} \mathrm{P}_{45} \mathrm{~K}_{45}+\mathrm{N}_{60}$ & 0,86 & 4,64 & 7,18 & 4,03 \\
\hline & $\mathrm{N}_{30} \mathrm{P}_{45} \mathrm{~K}_{45}+\mathrm{N}_{30}$ & 0,82 & 4,68 & 7,16 & 4,12 \\
\hline \multirow{5}{*}{$\begin{array}{c}\text { 3-й строк сівби - } \\
\text { через } 10 \text { днів }\end{array}$} & без добрив (контроль) & 0,60 & 4,10 & 7,23 & 3,89 \\
\hline & $\mathrm{P}_{45} \mathrm{~K}_{45}$ & 0,65 & 4,34 & 7,38 & 4,12 \\
\hline & $\mathrm{N}_{30} \mathrm{P}_{45} \mathrm{~K}_{45}$ & 0,89 & 4,93 & 7,92 & 4,45 \\
\hline & $\mathrm{N}_{30} \mathrm{P}_{45} \mathrm{~K}_{45}+\mathrm{N}_{60}$ & 0,83 & 4,72 & 7,62 & 4,32 \\
\hline & $\mathrm{N}_{30} \mathrm{P}_{45} \mathrm{~K}_{45}+\mathrm{N}_{30}$ & 0,86 & 4,80 & 7,62 & 4,39 \\
\hline & $\mathrm{IP}_{05}$ & 0,14 & 0,31 & 0,67 & 0,32 \\
\hline
\end{tabular}


СІЛЬСЬКЕ ГОСПОДАРСТВО. РОСЛИННИЦТВО

2. Вилив строків сівби і доз мінеральних добрив на формування фотосинтетичного потенціалу посіву рижію ярого, середнє за 2011-2013 рр., млн $\mathrm{M}^{2} / 2 а$ за добу

\begin{tabular}{|c|c|c|c|c|}
\hline \multirow{2}{*}{ Строк сівби } & \multirow{2}{*}{$\begin{array}{c}\text { Варіант } \\
\text { удобрення }\end{array}$} & $\begin{array}{c}|c| \\
\text { стеблування - } \\
\text { бутонізації }\end{array}$ & $\begin{array}{c}\text { бутонізація - } \\
\text { цвітіння }\end{array}$ & $\begin{array}{c}\text { цвітіння - початок } \\
\text { дозрівання }\end{array}$ \\
\cline { 2 - 5 } & без добрив & 0,076 & 0,191 & 0,130 \\
\hline \multirow{3}{*}{$\begin{array}{c}\text { 1-й строк сівби - } \\
\text { температура } \\
\text { грунту 1-2 }\end{array}$} & $\mathrm{P}_{45} \mathrm{~K}_{45}$ & 0,083 & 0,200 & 0,134 \\
\cline { 2 - 5 } & $\mathrm{N}_{30} \mathrm{P}_{45} \mathrm{~K}_{45}$ & 0,094 & 0,204 & 0,139 \\
\cline { 2 - 5 } & $\mathrm{N}_{30} \mathrm{P}_{45} \mathrm{~K}_{45}+\mathrm{N}_{60}$ & 0,092 & 0,205 & 0,141 \\
\cline { 2 - 5 } & $\mathrm{N}_{30} \mathrm{P}_{45} \mathrm{~K}_{45}+\mathrm{N}_{30}$ & 0,093 & 0,204 & 0,139 \\
\hline \multirow{5}{*}{$\begin{array}{c}\text { 2-й строк - } \\
\text { через 5 днів }\end{array}$} & без добрив & 0,069 & 0,175 & 0,114 \\
\cline { 2 - 5 } & $\mathrm{P}_{45} \mathrm{~K}_{45}$ & 0,074 & 0,180 & 0,121 \\
\cline { 2 - 5 } & $\mathrm{N}_{30} \mathrm{P}_{45} \mathrm{~K}_{45}$ & 0,084 & 0,189 & 0,133 \\
\cline { 2 - 5 } & $\mathrm{N}_{30} \mathrm{P}_{45} \mathrm{~K}_{45}+\mathrm{N}_{60}$ & 0,085 & 0,192 & 0,139 \\
\cline { 2 - 5 } & $\mathrm{N}_{30} \mathrm{P}_{45} \mathrm{~K}_{45}+\mathrm{N}_{30}$ & 0,083 & 0,190 & 0,136 \\
\hline \multirow{5}{*}{$\begin{array}{c}\text { 3-й строк - } \\
\text { через 10 днів }\end{array}$} & $\mathrm{P}_{45} \mathrm{~K}_{45}$ & 0,073 & 0,184 & 0,122 \\
\cline { 2 - 5 } & $\mathrm{N}_{30} \mathrm{P}_{45} \mathrm{~K}_{45}$ & 0,082 & 0,190 & 0,133 \\
\cline { 2 - 5 } & $\mathrm{N}_{30} \mathrm{P}_{45} \mathrm{~K}_{45}+\mathrm{N}_{60}$ & 0,091 & 0,195 & 0,141 \\
\cline { 2 - 5 } & $\mathrm{N}_{30} \mathrm{P}_{45} \mathrm{~K}_{45}+\mathrm{N}_{30}$ & 0,089 & 0,197 & 0,142 \\
\cline { 2 - 5 } & $\mathrm{HIP}_{05}$ & 0,006 & 0,008 & 0,004 \\
\hline
\end{tabular}

Так, у фазу стеблування площа листкової поверхні була в межах від 0,075 до 1,15 тис. м²/га. У фазі бутонізації даний показник на контролі

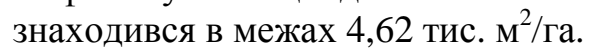

За внесення різних доз мінеральних добрив площа листкової поверхні зросла, в середньому, від 0,65 до 0,71 тис. $\mathrm{m}^{2} / г$ залежно від варіанту удобрення.

Найвища площа листкової поверхні була у фазу цвітіння рижію ярого. Так, у контрольному варіанті даний показник становив 8,80 тис. м $^{2} / г а$, а за внесення мінеральних добрив у дозі $\mathrm{N}_{30} \mathrm{P}_{45} \mathrm{~K}_{45}$ збільшився до 9,22 тис. $\mathrm{M}^{2} /$ га.

У фазі дозрівання площа листкової поверхні була в межах від 4,39 тис. м²/га на контролі й близько 5,15 тис. $\mathrm{m}^{2} /$ га - за внесення мінеральних добрив у дозі $\mathrm{N}_{30} \mathrm{P}_{45} \mathrm{~K}_{45}$.

Найменші показники площі листкової поверхні були відмічені нами за другого строку сівби на всіх фазах розвитку рослин рижію ярого.

Аналізуючи показники фотосинтетичного потенціалу посівів рижію ярого протягом вегетації, слід зазначити, що даний показник від початку вегетації до фази цвітіння зростав, після чого спостерігалось його зниження.

Така закономірність простежувалася за всіх строків сівби. Водночас, було виявлено залежність фотосинтетичного потенціалу від дози удобрення та застосування гербіциду: зі збільшенням дози удобрення спостерігалося збіль- шення показника фотосинтетичного потенціалу за всіх сроків сівби по всіх фазах росту культури (табл. 2).

Отже, на показники фотосинтетичного потенціалу у посівах рижію ярого значно впливають фактори, що вивчалися у досліді.

Встановлено, що внесення мінеральних добрив дозою $\mathrm{N}_{30} \mathrm{P}_{45} \mathrm{~K}_{45}+\mathrm{N}_{60}$ за першого строку сівби забезпечує формування максимальної величини фотосинтетичного потенціалу рижію ярого.

Висновок. Дані експериментів свідчать: в умовах Прикарпаття України формування більшої площі листкової поверхні рослин рижію ярого позитивно впливало на інтенсивність процесу фотосинтетичної продуктивності, яка залежала від строку сівби, мінеральних добрив і фази росту й розвитку рослин. Встановлено, що внесення в основне удобрення мінеральних добрив дозою $\mathrm{N}_{30} \mathrm{P}_{45} \mathrm{~K}_{45}$ за першого строку сівби забезпечує формування максимальних показників площі листкової поверхні впродовж вегетаційного періоду рижію ярого, які складали: у фазі стеблування $-1,15$ тис. $\mathrm{m}^{2} /$ га, а у фазі бутонізації 5,31 тис. $\mathrm{m}^{2} /$ га, у фазу цвітіння - 9,22 тис. $\mathrm{m}^{2} /$ га та у фазі дозрівання $-5,15$ тис. $\mathrm{m}^{2} /$ га. Динаміка фотосинтетичного потенціалу подібна до тієї, за якою формується площа листкової поверхні рослин. 


\section{БІБЛІОГРАФІЯ}

1. Бондаренко Г. Л. Методика дослідної справи в овочівництві і баштанництві / Бондаренко Г. Л., Яковенко К. І. - Харків : Основа, 2001. $370 \mathrm{c}$.

2. Мойсейченко В. Ф. Основы научных исследований в агрономии / В.Ф. Мойсейченко, М. Ф. Трифонова, А. Х. Заверюха, В. А. Ещенко. - М. : Колос, 1996. - 336 с.

3. Ничипорович A. А. Фотосинтетическая деятельность и пути повышения её продуктивности / А. А. Ничипорович. - В сб.: Теоретические основы фотосинтетической продуктивности. М. : Наука, 1972. - С. 12-16.

4. Фотосинтетическая деятельность растений в посевах / [А. А. Ничипорович, Л. Е. Строганова, С. Н. Чмора, М. П. Власова]. - М. : Изд. АН CCCP, 1961. - $136 \mathrm{c}$.

5. Goenadi D. H. Chfracteriration and potential use of humic acid as new gronth promoting substances // Brighton Crop Prot. Konf. : Weedz / Brighton. - 1995. - 20-23, Vol. 1. - P. 19-25. 